\title{
Pengaruh Persepsi Kegunaan, Persepsi Kemudahan, Kepuasan, Kualitas Sistem, dan Pemahaman Wajib Pajak Terhadap Minat Wajib Pajak Orang Pribadi (WPOP) Dalam Penggunaan E-Filing
}

\author{
Abraham Agung $^{1 *}$, Rinabi Tanamal ${ }^{2}$ \\ ${ }^{1,2}$ Program Studi Teknik Informatika, Universitas Ciputra, Surabaya, Jawa Timur \\ Email: ${ }^{1 *}$ agungabraham@gmail.com, ${ }^{2}$ r.tanamal@ ciputra.ac.id
}

(Naskah masuk: 23 Mei 2021, direvisi: 24 Jun 2021, diterima: 28 Jun 2021)

\begin{abstract}
Abstrak
Pajak ialah komponen penting yang mempengaruhi penerimaan pendapatan pada suatu negara. Tingkat kepatuhan wajib pajak yang rendah bisa berakibat pada kecilnya pemasukan kas negara, jadi bisa mengganggu kinerja pemerintah, karena mayoritas pengeluaran negara anggarannya dari penerimaan pajak. Supaya penerimaan pajak bisa maksimal, Dirjen Pajak melaksanakan moderenisasi pada sistem perpajakan dengan diciptakannya e-filing. Realisasi Pelaporan SPT Tahunan di Kanwil DJB Jawa Timur I, per 31 Mei 2018 baru sekitar 287.228 jumlah wajib pajak dari 363.397 wajib pajak yang wajib melaporkan SPT, artinya kepatuhan wajib pajak masih sekitar 79,04\%. Kemudian dari 287.228 SPT, yang dilaporkan melalui fasilitas $e$-filing sebanyak 240.349. Hal ini dapat diartikan bahwa masyarakat Surabaya sudah mulai mau menggunakan sistem e-filing, namun dalam penngunaannya masih belum maksimal. Berdsarkan latar belakang yang sudah dijabarkan, maka peneliti berkeinginan mengetahui apakah faktor persepsi kegunaan, kemudahan, persepsi kepuasan, kualitas sistem, pemahaman wajib pajak dapat berpengaruh terhadap minat Wajib Pajak Orang Pribadi (WPOP) untuk memakai sistem $e$-filing. Dalam penelitian ini memakai data primer dengan teknik survei yang mempergunakan media angket. Populasinya yaitu para WPOP yang tercatat dan memakai $e$-filling di KKP wilayah Surabaya. Dalam mengambil sampelnya menggunakan accidental sampling. Sampel pada penelitian sejumlah 100 responden dan ditetapkan menggunakan rumus slovin. Analisis datanya menggunakan regresi linier berganda. Teori yang dipakai adalah teori TAM.
\end{abstract}

Kata Kunci: Kegunaan, Kemudahan, Kualitas, Kepuasan, E-filing, Wajib Pajak, Technology Acceptance Model (TAM).

\section{The Effect of Use Perception, Perception of Easiness, Satisfaction, System Quality, and Taxpayer Understanding of Taxpayer's Interests in the Use of E-Filing}

\begin{abstract}
Taxes are an important component that affects revenue receipts in a country. The low level of taxpayer compliance can result in small state treasury income, so it can interfere with the government's performance, because the majority of state budget expenditures come from tax revenues. So that tax revenues can be maximized, the Director General of Taxes carries out modernization of the tax system by creating e-filing. Realization of Annual SPT Reporting at the DJB Regional Office of East Java I, as of May 31, 2018, there were only about 287,228 total taxpayers out of 363,397 taxpayers who were required to report SPT. This means that taxpayer compliance is still around $79.04 \%$. Then out of 287,228 SPTs that reported through the e-filing facility, 240,349 were reported. This can be interpreted that the Surabaya community has started to want to use the e-filing system, but its use is still not optimal. Based on the background that has been described, the researcher wants to know whether the perceived usefulness, convenience, satisfaction perception, system quality, understanding of taxpayers can affect the interest of individual taxpayers (WPOP) to use the e-filing system. In this study, primary data was used with a survey technique using a questionnaire. The population is WPOP registered and using e-filling in KKP Surabaya area. In taking the sample using accidental sampling. The sample in the study amounted to 100 respondents and was determined using the Slovin formula. Analysis of the data using multiple linear regression. The theory used is the TAM theory.
\end{abstract}

Keywords: Usability, Ease, Quality, Satisfaction, E-filing, Taxpayers, Technology Acceptance Model (TAM). 


\section{PENDAHULUAN}

\section{A. Latar Belakang}

Dalam pemerintahan NKRI, penerimaan negara tahun 2016 yang bersumber dari pajak berperan vital dalam pemasukan kas negara, yakni sebesar $74,6 \%$ dari total pemasukan negara. Penerimaan pajak di Indonesia mengalami kenaikan yang cukup baik, namun masih belum maksimal. Data dari situs web DJP, jumlah wajib pajak yang terdaftar per 31 Maret 2018 ialah 38.651.881. Dari data tersebut sejumlah 17.653.963 berkewajiban menyampaikan SPT. Wajib pajak yang sudah menyampaikan SPT tahun pajak 2017 sampai per 31 Maret 2018 baru 10.589.648 atau baru $59,98 \%$. Penerimaan pajak diperkirakan hanya mencapai $80 \%$. Dari data bersangkutan memperlihatkan pajak di negara ini belum optimal. Ketaatan dalam menyampaikan SPT sangatlah penting dikarenakan untuk menilai tax ratio dan kemandirian bangsa. [1].

Meskipun saat ini e-filling dapat mempermudah penyampaian Surat Pemberitahuan (SPT), namun tidak jarang WPOP yang masih mempunyai pola pikir atau cara pandang penyampaian Surat Pemberitahuan (SPT) secara manual jauh lebih mudah daripada pelaporan SPT dengan $e$-filing.

Untuk meningkatkan penerimaan pajak, Dirjen Pajak melakukan modernisasi pada sistem perpajakan yaitu $E$-filing. Realisasi pelaporan SPT Tahunan di Kanwil DJB Jawa Timur 1, per 31 Mei 2018 baru mencapai 287.228 wajib pajak dari 363.397 wajib pajak yang wajib melaporkan SPT, artinya kepatuhan wajib pajak masih sebesar 79,04 persen. Lalu dari 287.228 SPT yang melaporkan melalui fasilitas $e$-filing sebayak 240.349. Hal ini dapat diartikan bahwa masyarakat Surabaya sudah mulai mau mengunakan sistem $e$-filing, namun dalam pegunaannya masih belum maksimal. Dari hasil latar belakang yang sudah diuraikan, Technology Acceptance Model (TAM) dapat menjadi acuan analisis atas beberapa faktor yang dapat digunakan untuk penelitian sistem $e$-filing.

\section{B. Rumusan Masalah}

Sesuai dengan latar belakang yang ada, maka peneliti merumuskan masalah sebagai berikut "Apakah persepsi kegunaan, persepsi kemudahan, persepsi kepuasan, kualitas sistem dan pemahaman wajib pajak berpengaruh terhadap minat Wajib Pajak Orang Pribadi dalam penggunaan $e$ filling?"

\section{Manfaat Penelitian}

1. Manfaat Teoritis

Hasil penelitian ini diharapkan dapat memberikan pengetahuan tentang pengaruh persepsi kegunaan, persepsi kemudahan, persepsi kepuasan, kualitas sistem, dan pemahaman Wajib Pajak terhadap minat Wajib Pajak Orang Pribadi dalam penggunaan $e$-filling.

Penelitian ini diharapkan dapat menjadi bahan referensi untuk penelitian selanjutnya.

\section{Manfaat Praktisi}

Data hasil penelitian dapat digunakan sebagai referensi ataupun pertimbangan oleh DJP dalam hal pengembangan sistem $e$-filing

\section{LANDASAN TEORI}

\section{A. Technology Acceptance Model (TAM)}

Technology Acceptance Model (TAM) ialah sebuah model yang dipergunakan mempelajari beberapa faktor yang bisa memberikan pengaruh pada penerimaan penggunaan teknologi. TAM ditujukan untuk mengetahui faktor-faktor penentu diterimanya sebuah teknologi yang berbasis informasi. Peneliti dapat mengetahui mengapa suatu sistem mempunyai kemungkinan tidak diterima oleh user, sehingga dibutuhkan untuk mengambil tindakan perbaikan untuk mengatasinya [2]. Berdasar TAM, ada 2 faktor yang dominan berpengaruh pada integrasi teknologi, yakni persepsi kegunaan (usefulness), yakni melalui sistem bersangkutan ( $e$ filing) akan bermanfaat bagi penggunanya dan kinerjanya akan meningkat, dan persepsi kemudahan pada pemakaian teknologi (ease of use), yakni WP merasakan kemudahan dalam mengoperasikan sistem $e$-filling dan bisa memahami secara mandiri [3].

\section{B. Persepsi Kegunaan (Perceived Usefulness)}

Sebuah kepercayaan user atas penggunaan sebuah teknologi bisa mengakibatkan kinerja pekerjaannya meningkat. Berdasar pernyataan tersebut bisa dartikan yakni kegunaan persepsian (perceived usefulness) sebagai sebuah kepercayaan dalam proses ketika mengambil sebuah putusan. Bila individu mempercayai sistem informasi bermanfaat maka pengguna akan memakainya. [4].

\section{Persepsi Kemudahan (Perceived Ease of Use)}

Sebuah kepercayaan user atas penggunaan sebuah teknologi akan terbebas dari usaha. Persepsi kemudahan sebagai sebuah kepercayaan atas proses dalam mengambil sebuah putusan. Bila individu mempercayai sistem informasi mudah penggunaannya maka pengguna akan memakainya [4].

\section{Kepuasan}

Kepuasan ialah satu keyakinan user yang didapatkan dari ekspektasi ataupun harapan user terhadap sebuah produk yang telah dipergunakan oleh user tersebut [5]

\section{E. Kualitas Sistem}

Pengertian dari sebuah sistem dapat menunjukkan seberapa bagus sebuah sistem yang ketika digunakan oleh user dapat bekerja secara maksimal dan tidak mengalami kendala. [6].

\section{F. Pemahaman Wajib Pajak}

Pemahaman WP ialah sebagaimana WP mengetahui dan mempelajari aturan perpajakan yang diberlakukan. WP yang mendalami peraturan secara baik, terlihat dari tindakannya yang sesuai dengan peraturan. WP paham atas PP No.23 tahun 2018 dengan baik, pemahamannya ini terlihat dari yang WP laksanakan. WP yang paham peraturan dengan baik akan 
berusaha memperbaki kesediaan dalam membayarkan pajak [7].

\section{G. Intensi Menggunakan (Intention to Use)}

Minat menggunakan ialah kecenderungan individu untuk senantiasa menggunakan sebuah teknologi. Taraf penggunaan suatu teknologi individu bisa dilihat dari sikap dan atensinya pada penggunaan teknologi bersangkutan, misalnya hasrat menambahkan peripheral pendukung, dorongan untuk senantiasa menggunakan dan kesediaan untuk membujuk pengguna lainnya [8].

\section{H. E-filing}

Dalam sistem e-filing sendiri adalah aplikasi layanan perpajakan untuk pembayaran pajak. Selain itu aplikasi ini dapat juga digunakan untuk keperluan menghitung pajak yang yang akan dibayarkan sesuai informasi yang disediakan [9].

\section{METODE PENELITIAN}

\section{A. Metodologi Penelitian}

Metode kuantitatif ialah sebuah metode yang dapat menyebutkan hasil analisis secara deskriptif, serta analisis menggunakan penghitungan statistik. Dengan adanya penelitian secara kuantitatif, penelitian tersebut akan menjadi terstruktur. Lalu instrumen yang digunakan berupa kuesioner untuk pengumpulan datanya dan sekaligus megujinya. Secara penjelasan dan secara hitungan statistik keluaran hasil penelitiannya [10].

\section{B. Kerangka Konseptual}

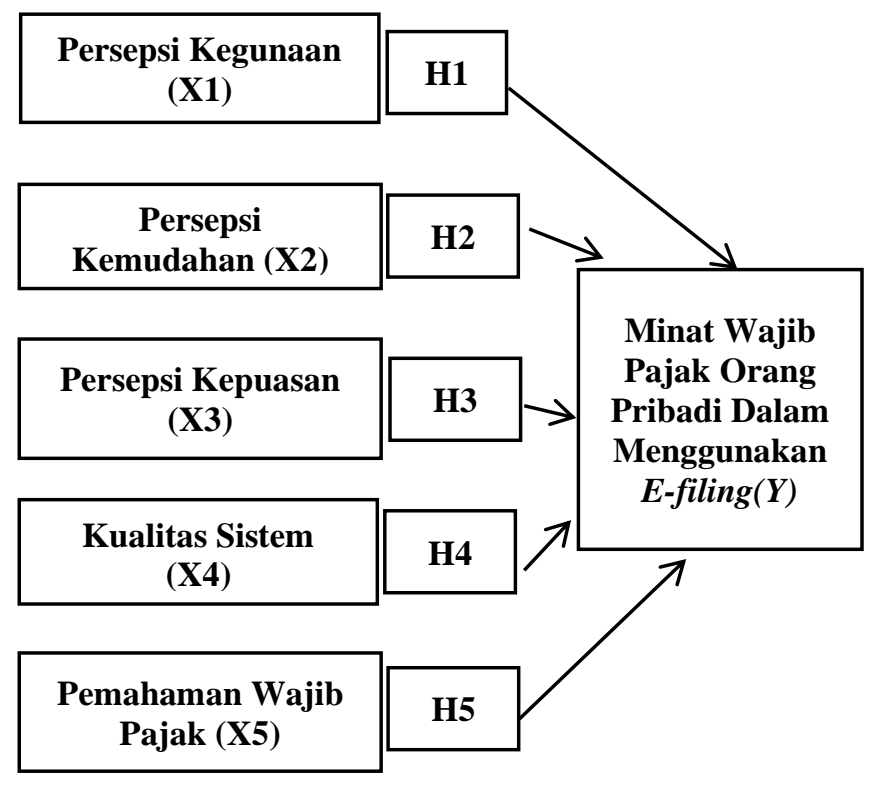

Gambar 1. Kerangka Konseptual

\section{Perumusan Hipotesis}

Dari Gambar 1 model penelitian di atas, didapatkan hipotesis yang disajikan pada Tabel 1 sebagai berikut:
Tabel 1. Perumusan Hipotesis

\begin{tabular}{cl}
\hline H1 & $\begin{array}{l}\text { Persepsi Kegunaan berpengaruh signifikan terhadap } \\
\text { intensitas Wajib Pajak menggunakan } E \text {-Filling }\end{array}$ \\
\hline H2 & $\begin{array}{l}\text { Persepsi Kemudahan berpengaruh signifikan } \\
\text { terhadap intensitas Wajib Pajak menggunakan } E \text { - } \\
\text { Filling }\end{array}$ \\
\hline $\mathbf{H 3}$ & $\begin{array}{l}\text { Persepsi Kepuasan berpengaruh signifikan terhadap } \\
\text { intensitas Wajib Pajak menggunakan } E \text {-Filling }\end{array}$ \\
\hline $\mathbf{H 4}$ & $\begin{array}{l}\text { Kualitas Sistem berpengaruh signifikan terhadap } \\
\text { intensitas Wajib Pajak menggunakan } E \text {-Filling }\end{array}$ \\
\hline H5 & $\begin{array}{l}\text { Pemahaman Wajib Pajak berpengaruh signifikan } \\
\text { terhadap minat Wajib Pajak menggunakan } \text { E-Filling }\end{array}$ \\
\hline
\end{tabular}

\section{Metode Pengumpulan Data}

Pengumpulan data dilaksanakan dengan membagikan angket pada sampel penelitiannya. Angket yang dibagikan berupa sekumpulan pernyataan tentang permasalahan yang terkait dengan objek yang diteliti. Angket tersebut dibagikan pada wajib pajak yang sudah memakai $e$-filing dan tercatat di KKP Wilayah Surabaya. Peneliti memakai skala likert guna melihat intensitas tingkah laku wajib pajak ketika pemakaian e-filing dengan menetapkan skor yang berasal dari setiap pernyataan. Skala likert dipakai guna mengetahui perilaku, gagasan, dan persepsi individu ataupun organisasi tentang tanda-tanda sosial. Penelitian yang telah dilakukan peneliti menggunakan dua sumber data yakni data primer serta sekunder. Dalam hal ini sumber datanya berwujud hasil jawaban dari angket yang diserahkan pada responden.

\section{E. Populasi}

Populasi merupakan seluruh objek yang akan diselidiki dan mempunyai varian ataupun perbedaan yang mencakup objek atau subjek yang memiliki memiliki atribut serta karakteristik khusus yang jadi objek penelitian untuk didalami dan selanjutnya diberikan kesimpulan. Populasinya adalah WPOP yang tercatat menjadi Wajib Pajak e-filing di wilayah kota Surabaya.

\section{F. Sampel}

Sampel merupakan bagian ataupun wakil dari populasi yang didapatkan dari jumlah serta atribut yang ada ataupun digambarkan oleh populasinya. Teknik yang dipakai dalam pengambilan sampelnnya yaitu non probalility sampling dengan teknik penentuan sampel accidental sampling (sampel tanpa sengaja). Nonprobability sampling berarti cara pengambilan sampelnya dengan tidak diacak dan accidental sampling merupakan cara menentukan sampel dimana siapa saja yang memiliki karakteristik yang relevan dengan yang ditentukan oleh peneliti dapat menjadi respondennya. Rumus Slovin (Rumus 1) digunakan dalam penelitian untuk penentuan sampel dalam penelitian ini:

$n=\frac{N}{1+N(e)^{2}}$

dengan:

$n=$ Ukuran sampel 
$N=$ Ukuran populasi

$e=$ Taraf kesalahan pengambilan sampel $10 \%$

$n=\frac{240.349}{1+240.349(0,1)^{2}}=99.218$

Jumlah sampel dari penelitian ini adalah 100 responden dengan pembulatan keatas dari 99,218 (Rumus 2).

\section{G. Definisi Operasiolan Variabel}

Tabel 2. Operasional Variabel

\begin{tabular}{|c|c|c|}
\hline Variabel & Indikator & Uji \\
\hline $\begin{array}{l}\text { Persepsi } \\
\text { Kegunaan (X1) }\end{array}$ & $\begin{array}{l}\text { a. Bermanfaat meningkatkan } \\
\text { produktivitas. } \\
\text { b. Bermanfaat menyederhanakan } \\
\text { proses pelaporan pajak. } \\
\text { c. Bermanfaat meningkatkan } \\
\text { efektivitas pelaporan pajak. } \\
\text { d. bermanfaat untuk meningkatkan } \\
\text { performa pelaporan pajak }\end{array}$ & $\begin{array}{l}\text { Skala } \\
\text { Likert }\end{array}$ \\
\hline $\begin{array}{l}\text { Persepsi } \\
\text { Kemudahan } \\
\text { (X2) }\end{array}$ & $\begin{array}{l}\text { a. Mudah digunakan } \\
\text { b. Dapat dipelajari } \\
\text { c. Terampil }\end{array}$ & $\begin{array}{l}\text { Skala } \\
\text { Likert }\end{array}$ \\
\hline $\begin{array}{l}\text { Persepsi } \\
\text { Kepuasan (X3) }\end{array}$ & $\begin{array}{l}\text { a. Pelaporan pajak menjadi efisien. } \\
\text { b. Menghemat biaya dan energi. } \\
\text { c. Efektif. } \\
\text { d. Memperoleh informasi yang } \\
\text { dibutuhkan. } \\
\text { e. Memberi informasi sesuai format } \\
\text { yang dibutuhkan. } \\
\text { f. Puas dan bangga menggunakan } e \text { - } \\
\text { filing }\end{array}$ & $\begin{array}{l}\text { Skala } \\
\text { Likert }\end{array}$ \\
\hline $\begin{array}{l}\text { Kualitas Sistem } \\
\text { (X4) }\end{array}$ & $\begin{array}{l}\text { a. Sistem dinyatakan stabil serta } \\
\text { tidak mengalami kendala ketika } \\
\text { diakses. } \\
\text { b. Sistem yang bisa menjaga } \\
\text { keamanan serta data user ketika } \\
\text { melaporkan kewajiban pajaknya. }\end{array}$ & $\begin{array}{l}\text { Skala } \\
\text { Likert }\end{array}$ \\
\hline $\begin{array}{l}\text { Pemahaman } \\
\text { Wajib Pajak } \\
\text { (X5) }\end{array}$ & $\begin{array}{l}\text { a. Paham proses menghitung pajak } \\
\text { terhutang } \\
\text { b. Paham proses pembayaran } \\
\text { pajaknya } \\
\text { c. Paham langkah-langkah dalam } \\
\text { mengisi SPT } \\
\text { d. Paham langkah-langkah dalam } \\
\text { menyampaikan SPT } \\
\text { e. Paham terkait sanksi } \\
\text { keterlambatan. }\end{array}$ & $\begin{array}{l}\text { Skala } \\
\text { Likert }\end{array}$ \\
\hline $\begin{array}{l}\text { Minat } \\
\text { Penggunaan } \\
(Y)\end{array}$ & $\begin{array}{l}\text { a. Selalu memakai } e \text {-filing ketika } \\
\text { melaporkan pajaknya. } \\
\text { b. Memakai } e \text {-filing di masa } \\
\text { mendatang } \\
\text { c. Merekomendasikan } e \text {-filing ke } \\
\text { teman ataupun kerabat }\end{array}$ & $\begin{array}{l}\text { Skala } \\
\text { Likert }\end{array}$ \\
\hline
\end{tabular}

\section{PEMBAHASAN}

BAB IV akan dijelaskan tentang hasil analisis data yang didapat dari pengolahan SPSS dan yang merupakan poin penting pada penelitian ini.

Pada penelitian ini karakteristik responden merupakan Wajib Pajak Orang Pribadi yang menggunakan E-Filing dan terdaftar di KPP wilayah kota Surabaya. Peneliti ingin membuktikan apakah ada pengaruh atau ada hubungan serta melakukan pengujian terhadap teori yang digunakan dalam penelitian yang berkaitan dengan variabel yang digunakan yaitu kegunaan, kemudahan, kepuasan, kualitas sistem, dan pemahaman wajib pajak terhadap minat Wajib Pajak Orang Pribadi dalam penggunaan E-Filing. Untuk memperoleh hasil, maka peneliti mengumpulkan data dari responden dengan demografis seperti terlihat pada Tabel 3 sebagai berikut:

Tabel 3. Daftar Responden berdasarkan KPP Terdaftar

\begin{tabular}{|lrr|}
\hline \multicolumn{1}{c}{ Nama KPP } & Jumlah Responden & Persentase \\
\hline Sukomanunggal & 35 & $35 \%$ \\
\hline Sawahan & 13 & $13 \%$ \\
\hline Gubeng & 10 & $10 \%$ \\
\hline Genteng & 3 & $3 \%$ \\
\hline Pabean Cantikan & 5 & $5 \%$ \\
\hline Wonocolo & 7 & $7 \%$ \\
\hline Mulyorejo & 7 & $7 \%$ \\
\hline Simokerto & 8 & $8 \%$ \\
\hline Rungkut & 4 & $4 \%$ \\
\hline Karangpilang & 0 & $0 \%$ \\
\hline Tegalsari & 3 & $3 \%$ \\
\hline Krembangan & 0 & $0 \%$ \\
\hline Madya Surabaya & 5 & $5 \%$ \\
\hline Jagir & 0 & $0 \%$ \\
\hline Sukomanunggal & 35 & $35 \%$ \\
\hline Sawahan & 13 & $13 \%$ \\
\hline Gubeng & 10 & $10 \%$ \\
\hline Genteng & 3 & $3 \%$ \\
\hline Pabean Cantikan & 5 & $5 \%$ \\
\hline Wonocolo & 7 & $7 \%$ \\
\hline Mulyorejo & 7 & $7 \%$ \\
\hline Simokerto & 8 & $8 \%$ \\
\hline Rungkut & 4 & $4 \%$ \\
\hline Karangpilang & 0 & $0 \%$ \\
\hline Tegalsari & 3 & $3 \%$ \\
\hline Krembangan & 0 & $0 \%$ \\
\hline Madya Surabaya & 5 & $5 \%$ \\
\hline Jagir & 0 & $0 \%$ \\
\hline Total & 100 & $100 \%$ \\
\hline & & \\
\hline
\end{tabular}

Berdasarkan data yang didapatkan dari para responden, Penelitian ini didominasi oleh Wajib Pajak Orang Pribadi yang terdaftar di KPP Pratama Sukomanunggal yaitu sebesar $35 \%$.

\section{Uji Validitas}

Bertujuan untuk mengukur valid maupun tidaknya sebuah angket yang diberikan pada masing-masing variabel. Masing- 
masing pertanyaan ditiap variabel hipotesisnya harus bisa memperlihatkan kebenaran pengukuran. Pengujian validitas bermaksud untuk mengetahui valid tidaknya suatu angket seperti tersaji pada Tabel 4.

Tabel 4. Hasil Uji Validitas

\begin{tabular}{|c|c|c|}
\hline Indikator & $\begin{array}{c}\text { Pearson } \\
\text { Correlation }\end{array}$ & Sig. (2-Tailed) \\
\hline \multicolumn{3}{|c|}{ Persepsi kegunaan } \\
\hline X1.1 & $0,767 * *$ & 0,000 \\
\hline X1.2 & $0,784 * *$ & 0,000 \\
\hline X1.3 & $0,849 * *$ & 0,000 \\
\hline X1.4 & $0,879 * *$ & 0,000 \\
\hline \multicolumn{3}{|c|}{ Persepsi kemudahan } \\
\hline $\mathbf{X} 2.1$ & $0,612 * *$ & 0,000 \\
\hline $\mathrm{X} 2.2$ & $0,633 * *$ & 0,000 \\
\hline $\mathbf{X} 2.3$ & $0,754 * *$ & 0,000 \\
\hline $\mathrm{X} 2.4$ & $0,759 * *$ & 0,000 \\
\hline $\mathrm{X} 2.5$ & $0,580 * *$ & 0,000 \\
\hline \multicolumn{3}{|l|}{ Kepuasan } \\
\hline X3.1 & $0,646 * *$ & 0,000 \\
\hline X3.2 & $0,735 * *$ & 0,000 \\
\hline X3.3 & $0,808 * *$ & 0,000 \\
\hline X3.4 & $0,750 * *$ & 0,000 \\
\hline X3.5 & $0,730 * *$ & 0,000 \\
\hline \multicolumn{3}{|l|}{ Kualitas Sistem } \\
\hline X4.1 & $0,888 * *$ & 0,000 \\
\hline $\mathrm{X} 4.2$ & $0,846 * *$ & 0,000 \\
\hline \multicolumn{3}{|c|}{ Pemahaman Wajib Pajak } \\
\hline X5.1 & $0,771 * *$ & 0,000 \\
\hline X5.2 & $0,725 * *$ & 0,000 \\
\hline X5.3 & $0,764 * *$ & 0,000 \\
\hline X5.4 & $0,843 * *$ & 0,000 \\
\hline X5.5 & $0,580 * *$ & 0,000 \\
\hline \multicolumn{3}{|c|}{ Intensitas penggunaan $\boldsymbol{E}$-filing } \\
\hline Y1.1 & $0,699 * *$ & 0,000 \\
\hline Y1.2 & $0,807 * *$ & 0,000 \\
\hline Y1.3 & $0,770 * *$ & 0,000 \\
\hline Y1.4 & $0,766 * *$ & 0,000 \\
\hline
\end{tabular}

Pada Tabel 4 di atas dapat diketahui indikator pada instrument pada sig.(2 tailed) memiliki nilai signifikansi $\leq$ 0,05 hal tersebut menunjukan indikator instrumen valid.

\section{Uji Reliabilitas}

Pengujian ini dilakukan dengan mencermati konsistensi koefisien Cronbach's Alpha dari seluruh variabel yang dipergunakan. Datanya dikatakan reliable bila mempunyai nilai Cronbach's Alpha >0,60. Hasil pengujiannya akan ditampilkan pada Tabel 5 di bawah ini.
Tabel 5. Uji Reliabilitas

Realiability Statistic

Cronbach's Alpha Nof Items

$0,745 \quad 5$

\begin{tabular}{lr}
\multicolumn{2}{c}{ Item total Statistic } \\
\hline Variabel & $\begin{array}{c}\text { Cronbach's Alpha } \\
\text { If Item Deleted }\end{array}$ \\
\hline X1 & 0,656 \\
\hline $\mathbf{X 2}$ & 0,709 \\
\hline $\mathbf{X 3}$ & 0,709 \\
\hline $\mathbf{X 4}$ & 0,727 \\
\hline $\mathbf{X 5}$ & 0,650 \\
\hline
\end{tabular}

Pada Tabel 5 menampilkan hasil pengujian reliabilitas dengan pengujian Cronbachs Alpha, didapat:

1) Variabel Persepsi Kegunaan (X1) mempunyai nilai Cronbach Alpha 0,656 > 0,6 maka bisa diartikan jika indikator instrumennya reliable.

2) Variabel Persepsi Kemudahan (X2) mempunyai nilai Cronbach Alpha 0,709 > 0,6 maka bisa diartikan jika indikator instrumennya reliable.

3) Variabel Persepsi Kepuasan (X3) mempunyai nilai Cronbach Alpha 0,709 > 0,6 maka bisa diartikan jika indikator instrumennya reliable.

4) Variabel Persepsi Kualitas Sistem (X4) mempunyai nilai Cronbach Alpha 0,727 > 0,6 maka bisa diartikan jika indikator instrumennya reliable.

5) Variabel Persepsi Pemahaman Wajib Pajak (X5) mempunyai nilai Cronbach Alpha 0,650 > 0,6 maka bisa diartikan jika indikator instrumennya reliable.

\section{Uji Normalitas}

Uji Normalitas bertujuan mengukur apakah model regresinya normal. Uji normalitas dilaksanakan menggunakan uji Kolmogorov-Smirnov dengan tingkat siginfikansinya kurang dari 0,05, maka variabel dapat dikatakan lolos uji normalitas.

Tabel 6. Uji Normalitas

\section{One-Sample Kolmogorov-Smirnov Test}
Asymp. Sig. (2tailed)
0,200

Pada Tabel 6 dapat disimpulkan bahwa data terdistribusi secara normal karena memiliki nilai signifikansi signifikansi > 0,05 dalam uji normalitas Kolmogorov-Smirnov.

\section{Uji Multikolinearitas}

Salah satu cara yang dipakai dalam melihat ada tidaknya gejala multikolinearitas ialah dengan memakai nilai VIF dan Tolerance. Ketentuan yang digunakan yakni nilai VIF 10 dan Tolerance 0,10. Jika nilainya VIF $<10$ dan Tolerancenya > 0,10 artinya mengalami gejala multikolinearitas. 
Tabel 7. Uji Multikolonieritas

\begin{tabular}{|crc|}
\hline \multicolumn{3}{|c}{ Collinearity Statistics } \\
Model & Tolerance & VIF \\
\hline X1 & 0,574 & 1,743 \\
\hline X2 & 0,792 & 1,263 \\
\hline X3 & 0,785 & 1,273 \\
\hline X4 & 0,852 & 1,174 \\
\hline X5 & 0,738 & 1,356 \\
\hline
\end{tabular}

Pada tabel 7 menampilkan hasil dari pengujian multikoloniaritas, dan dapat dijabarkan sebagai berikut :

1) Variabel Persepsi Kegunaan (X1) mempunyai nilai Tolerance 0,574 dan Nilai VIF 1,743 maka dapat diartikan tidak terjadi multikolinearitas karena sudah sesuai dengan ketentuan yaitu nilai tolerance lebih besar dari 0,1 dan nilai VIF kurang dari 10.

2) Variabel Persepsi Kemudahan (X2) mempunyai nilai Tolerance 0,792 dan Nilai VIF 1,263 maka dapat diartikan tidak terjadi multikolinearitas karena sudah sesuai dengan ketentuan yaitu nilai tolerance lebih besar dari 0,1 dan nilai VIF kurang dari 10.

3) Variabel Persepsi Kepuasan (X3) mempunyai nilai Tolerance 0,785 dan Nilai VIF 1,273 maka dapat diartikan tidak terjadi multikolinearitas karena sudah sesuai dengan ketentuan yaitu nilai tolerance lebih besar dari 0,1 dan nilai VIF kurang dari 10.

4) Variabel Kualitas Sistem (X4) mempunyai nilai Tolerance 0,852 dan Nilai VIF 1,174 maka dapat diartikan tidak terjadi multikolinearitas karena sudah sesuai dengan ketentuan yaitu nilai tolerance lebih besar dari 0,1 dan nilai VIF kurang dari 10.

5) Variabel Pemahaman Wajib Pajak (X5) mempunyai nilai Tolerance 0,738 dan Nilai VIF 1,356 maka dapat diartikan tidak terjadi multikolinearitas karena sudah sesuai dengan ketentuan yaitu nilai tolerance lebih besar dari 0,1 dan nilai VIF kurang dari 10.

\section{Uji Liniearitas}

Data yang baik semestinya berkorelasi secara linear antara variabel bebas dan terikatnya. Apabila nilai signifikansinya linierity <0,05, maka dikatakan berkorelasi linier antara variabel bebas dan terikatnya.

Tabel 8. Uji Linieritas

\begin{tabular}{lrl}
\hline \multicolumn{1}{c}{ Variabel } & $\begin{array}{c}\text { Nilai } \\
\text { Signifikansi }\end{array}$ & Keterangan \\
\hline Persepsi Kegunaan & 0,000 & linier \\
\hline $\begin{array}{l}\text { Persepsi } \\
\text { Kemudahan }\end{array}$ & 0,000 & linier \\
\hline Persepsi Kepuasan & 0,000 & linier \\
\hline Kualitas Sistem & 0,002 & linier \\
\hline $\begin{array}{l}\text { Pemahaman Wajib } \\
\text { Pajak }\end{array}$ & 0,000 & linier \\
\hline
\end{tabular}

Pada Tabel 8 di atas, maka dapat disimpulkan bahwa semua variabel bebas pada penelitian ini mempunyai nilai signifikansi $<0,05$ yang mana sesuai dengan ketentuan yang dipakai pada penelitian ini. Jadi bisa ditarik kesimpulan jika seluruh variabel bebas dalam penelitian ini mempunyai korelasi linier pada variabel terikatnya.

\section{Analisis Regresi Linier Berganda}

Analisis Regresi linier berganda ialah guna melihat ada atau tidak adanya pengaruh serta keterkaitan antara variabel bebas pada variabel terikat.

\section{Tabel 9. Uji Regresi Linier Berganda}

\section{Model \\ B (Koefisien Regresi)}

Constant

Persepsi Kegunaan (x1)

0,326

Persepsi Kemudahan (X2)

Kepuasan (X3)

Kualitas Sistem (X4)

Pemahaman Wajib Pajak (X5)

0,128

Hasil model persamaan regresi sebagai berikut:

$\mathrm{Y}=0,090+0,326 \mathrm{X} 1+0,248 \mathrm{X} 2+0,272 \mathrm{X} 3+0,038 \mathrm{X} 4+$ $0,128 \times 5$

Penjabaran dari hasil di atas ialah:

a) Koefisien regresi variabel Pelayanan (X1) adalah 0,326; yang berarti bila variabel bebas lainnya bernilai tetap dan variabel $\mathrm{x} 1$ akan meningkat, keinginan WPOP dalam memakai E-Filing (Y) akan meningkat 0,326. Koefisien yang menunjukkan nilai yang positif memperlihatkan bahwa terdapat korelasi positif antara Kegunaan dengan Minat WPOP dalam memakai E-Filing.

b) Koefisien regresi variabel Pelayanan (X2) adalah 0,248; yang berarti bila variabel bebasnya bernilai tetap dan variabel kemudahan meningkat, keinginan Wajib Pajak Orang Pribadi (WPOP) dalam menggunakan E-Filing (Y) akan mengalami peningkatan sebesar 0,248. Koefisien bernilai positif artinya terjadi hubungan positif antara Kemudahan dengan Minat Wajib Pajak Orang Pribadi (WPOP) dalam memakai E-Filing.

c) Koefisien regresi variabel Kepuasan (X3) adalah 0,272; yang berarti bila variabel bebas lain nilainya tetap dan variabel kepuasan meningkat, keinginan Wajib Pajak Orang Pribadi (WPOP) dalam memakai E-Filing (Y) akan mengalami peningkatan sebesar 0,272. Koefisien bernilai positif artinya terjadi hubungan positif antara Kepuasan dengan Minat Wajib Pajak Orang Pribadi (WPOP) dalam memakai E-Filing.

d) Koefisien regresi variabel Kualitas Sistem (X4) adalah 0,038; yang berarti bila variabel bebas lain nilainya tetap dan variabel kepuasan meningkat, keinginan WPOP dalam memakai E-Filing (Y) akan meningkat 0,038. Koefisien bernilai positif berarti terdapat korelasi positif antara Kualitas Sistem dengan minat WPOP dalam memakai E-Filing. 
e) Koefisien regresi variabel Pemahaman Wajib Pajak (X5) adalah 0,128; yang berarti bila variabel bebas lainnya bernilai sama dan variabel pemahaman wajib pajak meningkat, keinginan WPOP dalam memakai E-Filing (Y) akan meningkat 0,128 . Koefisien yang nilainya positif berarti berkorelasi positif antara Pemahaman Wajib Pajak dengan Minat WPOP dalam memakai E-Filing.

\section{Uji Signifikansi Parsial (Uji T)}

Digunakan dalam melihat sebesar apa pengaruhnya setiap variabel bebasnya pada variabel terikatnya. Bila hasil pengujiannya menghasilkan nilai signifikansi $<0,05$ dan $T_{\text {hitung }}$ $>\mathrm{T}_{\text {tabel }}$ jadi variabel bebas secara individual mempengaruhi dengan signifikan pada variabel dependennya [11].

\begin{tabular}{|lcc|}
\multicolumn{2}{c}{ Tabel 10. Uji T } \\
Model & T & Sig. \\
\hline Persepsi Kegunaan (x1) & 3,006 & 0,003 \\
\hline Persepsi Kemudahan (X2) & 3,569 & 0,001 \\
\hline Kepuasan (X3) & 4,216 & 0,000 \\
\hline Kualitas Sistem (X4) & 0,742 & 0,460 \\
\hline Pemahaman Wajib Pajak (X5) & 1,612 & 0,110 \\
\hline
\end{tabular}

A) Variable persepsi kegunaan

Tabel tersebut memperlihatkan nilai signifikansi variabel Persepsi Kegunaan (X1) yaitu 0,000 yaitu < 0,05. Jadi bisa ditarik kesimpulan jika variabel Persepsi Kegunaan mempengaruhi secara signifikan terhadap Minat Penggunaan.

B) Variable Persepsi Kemudahan

Tabel tersebut memperlihatkan nilai signifikansi nyavariabel Persepsi Kemudahan (X2) yaitu 0,002 yaitu < 0,05. Jadi bisa ditarik kesimpulan jika variabel Persepsi Kemudahan mempengaruhi secara signifikan terhadap Minat Penggunaan.

C) Persepsi kepuasan

Tabel tersebut memperlihatkan nilai signifikansinya variabel Persepsi Kepuasan (X3) yaitu 0,000 yaitu <0,05. Jadi bisa ditarik kesimpulan jika variabel Persepsi Kepuasan mempengaruhi secara signifikan terhadap Minat Penggunaan

D) Kualitas Sistem

Tabel tersebut memperlihatkan nilai signifikansi variabel Kualitas Sistem (X4) yaitu sebesar 0,460 yaitu > 0,05. Jadi bisa ditarik kesimpulan jika variabel Kualitas Sistem tidak mempengaruhi secara signifikan terhadap Minat Penggunaan

E) Pemahaman Wajib Pajak

Tabel di atas memperlihatkan nilai signifikansinya variabel Pemahaman Wajib Pajak (X5) yaitu sebesar 0,110 yaitu > 0,05. Jadi bisa ditarik kesimpulan jika variabel Pemahaman Wajib Pajak tidak mempengaruhi secara signifikan terhadap Minat Penggunaan.

\section{Uji Signifikansi Simultan (Uji F)}

Taraf signfikansinya merupakan $\alpha=5 \%$ (signifikansinya $5 \%$ ataupun 0,05 merupakan ketentuan standar yang banyak digunakan pada penelitian). Disamping hal tersebut dapat pula diketahui dengan melihat nilai signifikansi. bila nilai signifikansinya $<0,05$ maka menerima Ha dan menolak Ha. Jika nilai signifikansi > 0,05 maka Ha dapat diterima serta Ho ditolak.

\begin{tabular}{|rcr|}
\multicolumn{3}{|c}{ Tabel 11. Uji F } \\
\hline \multicolumn{3}{|c|}{ Anova } \\
\hline Model & F & Signifikansi \\
\hline 1 & 25,386 & 0,000 \\
\hline
\end{tabular}

Sesuai Tabel 11 di atas didapatkan nilai signifikansi yaitu 0,000 yang mana $<0,05$, nilai tersebut sejalan menggunakan ketentuannya jadi bisa ditarik konklusi jika variabel Persepsi Kegunaan, Persepsi Kemudahan, Persepsi Kepuasan, Kualitas Sistem serta Pemahaman wajib Pajak secara stimultan serta mempunyai arah positif dalam mempengaruhi Minat Penggunaan E-Filing.

\section{Uji Koefisien Determinasi (R2 Square)}

Analisis koefisien determinasi dilaksanakan dengan tujuan untuk melihat sebesar apa kemampuan variabel bebasnya dalam menerangkan variabel terikatnya. Nilai $R$ Square dinyatakan baik apabila 0,5 sebab $R$ Square kisaran nilainya antara 0 hingga 1 [12].

Tabel 12. Uji Koefisien Determinasi

\begin{tabular}{rr|} 
Model & R Square \\
\hline 1 & 0,552 \\
\hline
\end{tabular}

Sesuai Tabel 12 di atas, diketahui nilai koefisien determinasi $0,552(55,2 \%)$. hasil tersebut mempunyai arti seluruh variabel bebas dalam penelitian ini memiliki pengaruh terhadap Minat Penggunaan sebanyak 55,2\%. serta 44,8\% sisanya dipengaruhi variabel lain diluar variabel penelitian ini.

\section{KESIMPULAN}

Setelah peneliti melakukan beberapa tahapan penelitian yakni penyusunan penelitian, metodologi penelitian, pengumpulan data, analisis data dan pengujian, maka didapatkan hasil yang bisa menjelaskan hubungan dari variabel yang dipergunakan yakni Persepsi Kegunaan, Persepsi Kemudahan, Persepsi Kepuasan, Kualitas Sistem dan Pemahaman Wajib Pajak. Semua variabel memiliki arah yang positif. Tetapi terdapat dua variabel yang tidak memiliki pengaruh secara parsial atau individual yaitu terdapat pada variabel Kualitas Sistem dan Pemahaman Wajib Pajak. 
Tabel 13. Hasil Pengujian Hipotesis

\begin{tabular}{lccl}
\hline \multicolumn{1}{c}{$\begin{array}{c}\text { Variabel } \\
\text { Independen }\end{array}$} & $\begin{array}{c}\text { Nilai } \\
\text { Signifikansi }\end{array}$ & $\begin{array}{c}\text { Nilai T } \\
\text { Hitung }\end{array}$ & $\begin{array}{c}\text { Hasil Uji } \\
\text { Hipotesisi } \\
\text { secara Pasial }\end{array}$ \\
\hline $\begin{array}{l}\text { Persepsi } \\
\text { Kegunaan } \\
(\mathrm{X} 1)\end{array}$ & 0,000 & 4,098 & $\begin{array}{l}\text { Hipotesis 1 } \\
\text { diterima. }\end{array}$ \\
\hline $\begin{array}{l}\text { Persepsi } \\
\text { Kemudahan } \\
\text { (X2) }\end{array}$ & 0,002 & 3,242 & $\begin{array}{l}\text { Hipotesis 2 } \\
\text { diterima. }\end{array}$ \\
\hline $\begin{array}{l}\text { Persepsi } \\
\text { Kepuasan } \\
\text { (X3) }\end{array}$ & 0,000 & 3,802 & $\begin{array}{l}\text { Hipotesis 3 } \\
\text { diterima. }\end{array}$ \\
\hline $\begin{array}{l}\text { Kualitas } \\
\text { Sistem X4 }\end{array}$ & 0,460 & 0,742 & $\begin{array}{l}\text { Hipotesis 4 } \\
\text { ditolak. }\end{array}$ \\
\hline $\begin{array}{l}\text { Pemahaman } \\
\text { Wajib Pajak } \\
\text { (X5) }\end{array}$ & 0,110 & 1,612 & $\begin{array}{l}\text { Hipotesis 5 } \\
\text { ditolak. }\end{array}$ \\
\hline & & & \\
\hline
\end{tabular}

Hasil yang diteliti dari variabel persepsi kegunaan mempengaruhi signifikan dan positif pada minat penggunaan. Dalam hal ini, hasil uji $\mathrm{T}$ memperlihatkan nilai signifikansinya 0,000 . Hal tersebut berarti dimensi persepsi kegunaan yang membahas mengenai manfaat kegunaan $E$ Filing mampu mempengaruhi minat penggunaan. Pada persamaan koefisien regresinya memiliki nilai 0,326 maknanya memiliki arah hubungan positif bila variabel persepsi kegunaan ditingkatkan maka minat penggunaan juga meningkat.

Hasil penelitian pada variabel persepsi kemudahan mempengaruhi signifikan positif pada minat penggunaan. Dalam hal ini, hasil uji $\mathrm{T}$ memperlihatkan nilai signifikansinya 0,002. Hal tersebut maknanya dimensi persepsi kemudahan yang membahas mengenai kemudahan penggunaan E-Filing mampu mempengaruhi minat penggunaan. Pada persamaan koefisien regresi memiliki nilai 0,248 maknanya mempunyai arah hubungan positif bila variabel persepsi kemudahan makin tinggi maka minat penggunaannya juga naik.

Hasil yang diteliti dari variabel persepsi kepuasan mempengaruhi signifikan positif pada minat penggunaan. Dalam hal ini, hasil uji $\mathrm{T}$ memperlihatkan nilai signifikansinya 0,000. Hal tersebut maknanya dimensi persepsi kepuasan yang membahas mengenai kesesuaian $E$ Filing pada harapan pengguna mampu mempengaruhi minat penggunaan. Pada persamaan koefisien regresi memiliki nilai 0,272 maknanya Tabel tersebut memperlihatkan arah hubungan positif bila variabel persepsi kepuasan makin tinggi maka minat penggunaannya juga naik.

Hasil penelitian pada variabel kualitas sistem tidak memengaruhi minat penggunaan namun arah hubungannya positif. Dalam hal ini, hasil uji $\mathrm{T}$ memperlihatkan nilai signifikansinya 0,460 . Hal tersebut maknanya dimensi kualitas sistem yang membahas mengenai stabilitas dan keamaan sistem $E$-Filing belum mampu mempengaruhi minat penggunaan. Variabel ini tidak memiliki pengaruh secara parsial dikarenakan pelapor pajak menggunakan E-Filing hanya dikarenakan efisiensi waktu yang tidak mengharuskan datang ke kantor pajak secara langsung. Meskipun tidak memiliki pengaruh, namun variabel kualitas sistem tetap memiliki arah pengaruh yang positif terhadap minat penggunaan. Pada persamaan koefisien regresi memiliki nilai 0,038 maknanya memiliki arah hubungan positif jika variabel kualitas sistem ditingkatkan maka minat penggunaan juga meningkat.

Hasil penelitian pada variabel pemahaman wajib pajak tidak memiliki pengaruh terhadap minat penggunaan namun memiliki arah hubungan positif. Dalam hal ini, hasil uji $\mathrm{T}$ memperlihatkan nilai signifikansinya 0,110 . Hal tersebut maknanya dimensi pemahaman wajib pajak yang membahas mengenai pemahaman pelapor pajak belum mampu mempengaruhi minat penggunaan. Variabel ini tidak memiliki pengaruh secara parsial dikarenakan pelapor pajak melaporkan SPT hanya dikarenakan hal tersebut wajib dilakukan, sehingga pelapor merasa tidak perlu pemahaman lebih mendalam asalkan sudah melakukan kewajibannya sebagai pelapor pajak. Meskipun tidak memiliki pengaruh, namun variabel pemahaman wajib pajak arah pengaruhnya positif terhadap minat penggunaan. Pada persamaan koefisien regresinya memiliki nilai 0,128 maknanya mempunyai arah hubungan positif jika variabel pemahaman wajib pajak ditingkatkan maka minat penggunaan juga meningkat.

Hasil dari seluruh variabel independen secara serentak memengaruhi Minat Penggunaan E-Filling. Hasil uji $\mathrm{F}$ memperlihatkan nilai signifikansinya 0,000. Variabel bebasnya mempunyai nilai koefisien determinasi yakni 0,552 , maka semua dimensi variabel bebasnya mempengaruhi minat penggunaan senilai $55,2 \%$.

\section{REFERENSI}

[1] Dewi, M.A. (2019). Pengaruh Persepsi Kegunaan, Persepsi Kemudahan, Keamanan Dan Kerahasiaan, Tingkat Kesiapan Teknologi Informasi Dan Kepuasan Pengguna Wajib Pajak Terhadap Intensitas Perilaku Wajib Pajak Dalam Penggunaan E-Filing. Jurnal Sains, Akuntansi dan Management (JSAM), Vol. 1(3), pp. 317367.

[2] Fayada, R. \& Paper, D. (2015). The Technology Acceptance Model E-Commerce Extension: A Conceptual Framework. Procedia Economics and Finance, Vol. 26, pp. $1000-1006$.

[3] Andi \& Sari, D.N. (2017). Faktor-Faktor Yang Memengaruhi Minat Wajib Pajak Orang Pribadi Dalam Penggunaan E-Filing Pada KPP Pratama Serang. SAINS: Jurnal Manajemen dan Bisnis, Vol. 10(1), pp. 41-65.

[4] Junawan \& Damanik, K.S. (2018). Pengaruh Persepsi Kebermanfaatan, Persepsi Kemudahan Penggunaan, dan Kepuasan Wajib Pajak Terhadap Penggunaan E-Filing bagi Wajib Pajak Orang Pribadi. Jurnal Akuntansi Bisnis dan Publik, Vol. 9(1), pp. 68-79.

[5] Rukmiyati, N.M.S. \& Budiartha, I.K. (2016). Pengaruh Kualitas Sistem Informasi, Kualitas Informasi Dan Perceived Usefulness Pada Kepuasan Pengguna Akhir 
Software Akuntansi (Studi Empiris Pada Hotel Berbintang Di Provinsi Bali). E-Jurnal Ekonomi dan Bisnis Universitas Udayana, Vol. 5(1), pp. 115-142.

[6] Haryanto, R. \& Widyastuti, P. (2018). Pengaruh Kualitas Sistem Dan Kualitas Informasi Terhadap Kepuasan Pengguna Dengan Persepsi Manfaat Sebagai Variabel Intervening. Journal for Business and Entrepreneur, Vol. 2(2), pp. 1-15.

[7] Pangesti, D.M. \& Yushita, A.N. (2019). Pengaruh Kesadaran Membayar Pajak, Persepsi Atas Efektivitas Sistem Perpajakan, Dan Pemahaman Peraturan Pemerintah Nomor 23 Tahun 2018 Terhadap Kemauan Membayar Pajak (Pada UMKM Sektor Perdagangan Di Kabupaten Klaten). Jurnal Nominal, Vol. 8(2), pp. 166178.

[8] Sarce, Malikah, A. \& Junaidi (2019). Analisis FaktorFaktor Yang Mempengaruhi Intensi Menggunakan Internet Banking Berbasis Technology Acceptance Model (TAM) (Studi Empiris Terhadap Nasabah Bank BCA di Kota Malang). Jurnal Ilmiah Riset Akuntansi, Vol. 8(5), pp. 109 - 119.
[9] Aminnudin, M., Ali \& Subadriyah. (2019). Peningkatan Kepatuhan Wajib Pajak melalui Penerapan Sistem Efilling yang Dimoderasi oleh Pemahaman Internet . BISNIS: Jurnal Bisnis dan Manajemen Islam, Vol. 7(1), pp. 93 - 112.

[10] Herdana, A. (2015). Analisis Pengaruh Kesadaran Merek (Brand Awareness) Pada Produk Asuransi Jiwa Prudential Life Assurance (Studi Pada Pru Passion Agency Jakarta). Jurnal Riset Bisnis dan Manajemen, Vol. 3(1).

[11] Tanamal, R. (2017). Analisis Faktor yang Paling Berpengaruh Pada Keinginan Menggunakan Applikasi Grab di Kota Surabaya. Jurnal Terapan Teknologi Informasi, Vol. 1(2), pp. 119 - 128.

[12] Dewi, M.A.C. (2019). Pengaruh Persepsi Kegunaan, Persepsi Kemudahan, Keamanan Dan Kerahasiaan, Tingkat Kesiapan Teknologi Informasi Dan Kepuasan Pengguna Wajib Pajak Terhadap Intensitas Perilaku Wajib Pajak Dalam Penggunaan E-Filing. Jurnal Sains, Akuntansi dan Management (JSAM), Vol. 1(3), pp. 317367. 